AGH DRILLING, OIL, GAS • Vol. 33 • No. 2 • 2016

http://dx.doi.org/10.7494/drill.2016.33.2.315

\author{
Vitalii Kulynych*, Michał Maruta**
}

\title{
ALOHA - MODERN TOOL FOR MODELING THE RISKS ASSOCIATED WITH THE SPREAD \\ OF VOLATILE POLLUTANTS IN EXTRACTION \\ OF HYDROCARBONS****
}

\section{INTRODUCTION}

Transportation, processing and exploitation of oil and natural gas associated with the risk of environmental contamination with petroleum and other chemicals. To assess these risks and factors that influence them, more oil companies (Schlumberger, Paradigm Geophysical, Total, BP, Royal Dutch Shell, Chevron, ConocoPhillips, Statoil Hydro, China National) began using the computer method of pollution modelling [3].

Computer simulations - i.e. the use of computers to solve problems by simulating theoretical models - are part of the new methodology, which for many years takes place next to the pure theory and experience. Simulations allow solving problems that cannot be tested experimentally, because they are difficult, dangerous or costly, or these problems are too complex for theoretical analysis. The main task of the method is a computer simulation of complex physical phenomena that occur in the natural environment, through the proper solution of mathematical equations derived based on a physical model. Computer methods involve converting the continuous model, appearing in the form of e.g. differential equations, in the form of discrete, which can be solved numerically. The use of numerical simulations in modelling the physical phenomena and their ability to interact with the experience in both laboratory and field trials, as well as to analysis, makes numerical calculations necessary tool in science [7].

* AGH University of Science and Technology, Faculty of Drilling, Oil and Gas, Krakow, Poland, PhD Student

** AGH University of Science and Technology, Faculty of Drilling, Oil and Gas, Krakow, Poland

*** Work performed within the statutory research program of the Faculty of Drilling, Oil and Gas AGH UST No. 11.11.190.555 
The main objective of this paper is to present a computer simulation of the hydrogen sulphide spread due to pipeline failure. The results of calculations will allow to estimate the danger zone and will support the decision to evacuate.

\section{RISKS ASSOCIATED DURING DRILLING OPERATION AND THE EXPLOITATION OF HYDROCARBON DEPOSITS CONTAINING HYDROGEN SULPHIDE}

Hydrogen sulphide $\left(\mathrm{H}_{2} \mathrm{~S}\right)$ is a colourless, highly toxic gas with a characteristic odour. The molecular weight of this compound is equal to $34.08 \mathrm{~g} / \mathrm{mol}$ and a density of $0.001539 \mathrm{~g} / \mathrm{cm}^{3}$. The hydrogen sulphide content of at $3.3-46 \%$ by volume in air produces an explosive mixture, it is also flammable substance. Hydrogen sulphide is also a product produced by bacteria in the digestion of animal and vegetable proteins. At the same time elevated levels of this substance can be observed in the production of sulfuric acid, carbon disulphide, colorants in factories of rayon and pulp, in the coke plant and gasworks [4]. In nature, it occurs in volcanic gases, in some mineral waters and accompanied by deposits of oil and natural gas.

Hydrogen sulphide occurs almost exclusively in deposits accumulated in carbonate rocks (limestones and dolomites). In Poland, the content of this gas in oil and natural gas deposits is varied, ranging from 0 to several tens of percent.

In terms of potential eruption and hydrogen sulphide hazards in Poland can be isolated areas of (Fig. 1):

- Low hazard, regions of the Carpathian Mountain and the Carpathian Foredeep.

- Medium hazard, region of the Lublin Monocline.

- Very high hazard, regions of the Fore-Sudetic Monocline and NW part of the Polish Lowland [12].

Threats to the environment during the drilling operations, occur usually in a small area, for a short time and generally on a small scale. Especially open eruptions, that is, uncontrolled flows of mud or reservoir fluids containing hydrogen sulphide at which the gas is released into the atmosphere, are a serious threat to people, living organisms and the environment. Underground eruptions (uncontrolled fluid flows between the reservoir rocks), drilling or reservoir fluids may lead to penetration of hydrogen sulphide into groundwater, rocks or soil. The hydrogen sulphide threat may also be related to the corrosive impact of $\mathrm{H}_{2} \mathrm{~S}$ on elements of surface and downhole well equipment and the drill string. The resulting damage of drilling equipment can result in an outflow of $\mathrm{H}_{2} \mathrm{~S}$ to the surface. The greatest risk of emergency situations (including the eruption) there is at the stage of exploration (development and DST (Drill Stem Test)) deposits contain hydrogen sulphide [10].

During the exploitation of hydrocarbon deposits, emissions of hydrogen sulphide contained in natural gas may take place with the following devices: production well 
heads, casing, pumps, valves, pipelines, in the case of oil deposits, they can also be separators and oil tanks. During routine work, hydrogen sulphide can escape from the ventilation systems, the flare stack (in which is combusted gas accompanying crude oil) and valves. During the filling and emptying of transport equipment and oil storage tanks can reach up to the evaporation of hydrogen sulphide. Potential sources of emission can also be reservoir water tanks, in which the $\mathrm{H}_{2} \mathrm{~S}$ is emitted from the extracted water at the surface or which is produced by the activity of anaerobic bacteria. Hydrogen sulphide can also be emitted from the well through the leaky casing, cement stone or cement plug $[9,10]$.

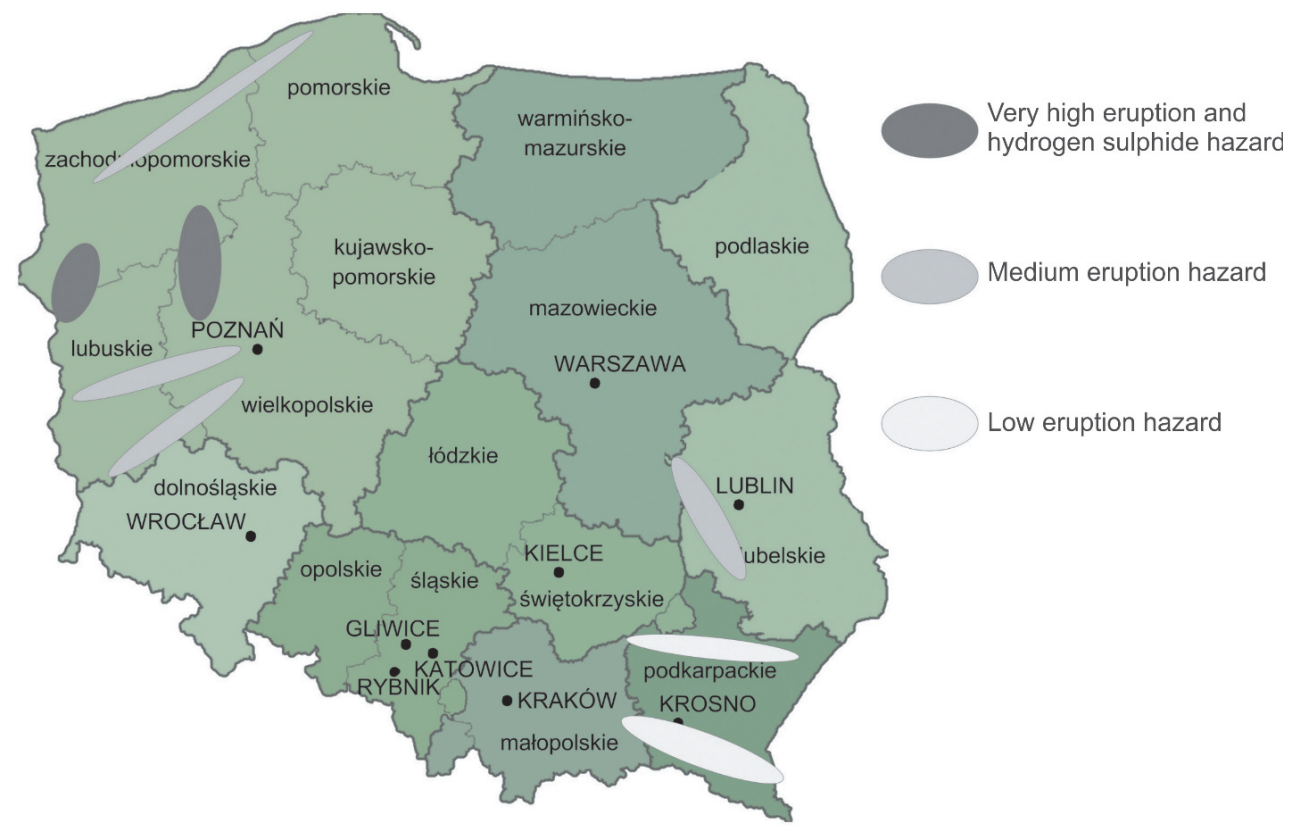

Fig. 1. Areas of the potential eruption hazards, after [12], modified

\section{DESCRIPTION OF THE SOFTWARE}

Program ALOHA was developed by the US Environmental Protection Agency and the US National Oceanic and Atmospheric Administration, is used during spills of chemicals as support to estimate the areas of toxic fumes hazardous to health and life, as well as thermal radiation or volume growth pressure after the explosion (explosion wave). The simulation results spread of analysed substances are presented in graphical form, as an area whose boundaries can be defined by the user as needed. These results can be transferred to the map to determine the risk of objects, quantities and determine the number of people in each zone. The advantage of the program is compatible with most 
popular operating systems. In addition, ALOHA has an easy to use interface which is based on information generally available to rescuers during rescue operations such as weather conditions, the type of chemical and basic data about the characteristics of release. ALOHA allows the user to input the amount of substances released into the environment, the type of installation (tank, pipeline), the size of leaks, medium temperature, the pressure, physical state, etc. Entered data are subject to verification by the program in terms of connectivity, in order to reduce user error. Errors are displayed in the form of messages, and the change mistakenly entered date enables further work with the program. The application is based on two models of the dispersion. Gaussian model - used to gases whose density is close to the density of the air; according to the assumptions of the model wind and atmospheric turbulence are the forces determining the spread process of the "cloud of chemical" in all directions. Graphical presentation of the gaseous substance concentration resembles a Gauss bell curve distribution (Fig. 2).

a)

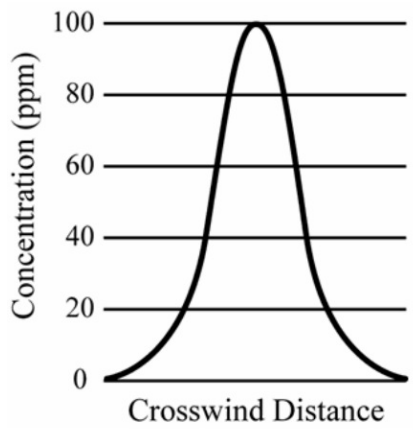

b)

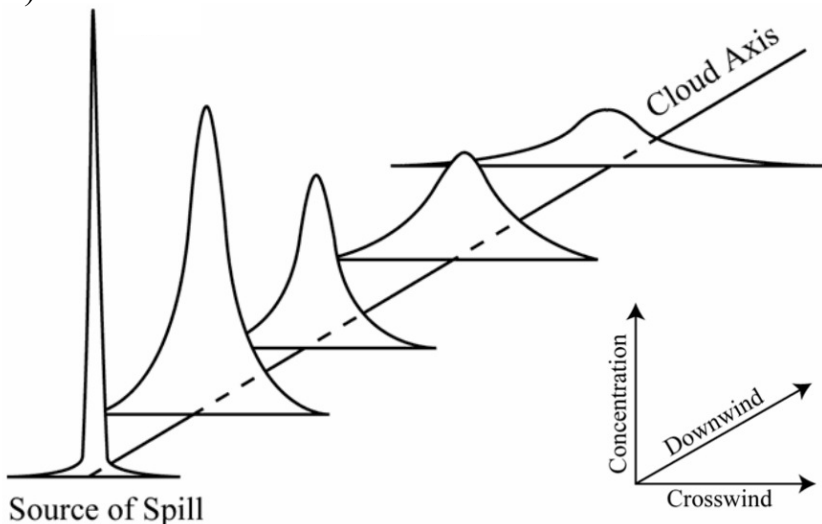

Fig. 2. Gaussian distribution (a), Gaussian spread (b) [11]

Immediately after the emission, the shape of the curve is similar to the peak due to the limited possibility of dispersion in the atmosphere, but with the passage of time since the event maximum of the bell curve is reduced and enlargement. Model "heavy gas" apply to the gas, whose density is higher than $1100 \mathrm{~kg} / \mathrm{m}^{3}$. At the beginning of the event the escaping gas leak or descends rapidly to the surface due to the density difference compared with the ambient air. Then, the gravitational force causing the horizontal spread of the gas on the surface, which in effect increases the range of influence compared to place of leak. Together with dilution gas cloud atmospheric air, its density decreases, and in a situation when the concentration of "heavy gas" falls below $1 \%$ pollutants becomes very susceptible to fluctuations due to atmospheric turbulence and wind [1].

Databases included in the program include physical, chemical and toxicological data of several hundred chemicals and geographical location for many cities in the United States but it is also possible to add new locations to the database. ALOHA 
is designed for leaks at scales most commonly occur during traffic accidents, and the duration of the phenomenon was limited to 60 minutes. The program also has other restrictions involving the inability to determine the zones considering the change in height of the zone in relation to the ground and at low wind speeds, or lack thereof. Despite the limitations has a lot of advantages, and is useful not only in activity but also the prediction hazards $[2,6]$.

\section{MODELLING \\ OF THE CHEMICAL SUBSTANCES DISPERSION WITH ALOHA SOFTWARE}

\subsection{Analysis of a sudden release of a hazardous substance case}

It was assumed that the sudden release of hydrogen sulphide occurs due to failure of the transmission pipeline.

In this case, we set up a continuous emission of dangerous substance lasted for 60 minutes. In the initial phase of data input we define basic information about the geographical location of an industrial facility, in the case a transmission pipeline, which is located near the "R" field. The "R" deposit is located in the central-west part of Poland in the Main Dolomite (Ca2) carbonates in the Polish Lowland. Next we select hydrogen sulphide $\left(\mathrm{H}_{2} \mathrm{~S}\right)$ from the chemical substances database. Then we define the meteorological conditions parameters under which will be carried out simulation (Tab. 1).

Table 1

Meteorological parameters

\begin{tabular}{|l|c|}
\hline Wind direction & $\mathrm{NW}$ \\
\hline Wind speed & $7 \mathrm{~m} / \mathrm{s}$ \\
\hline Air temperature & $21^{\circ} \mathrm{C}$ \\
\hline Atmosphere stability class & neutral \\
\hline Relative humidity & $64 \%$ \\
\hline
\end{tabular}

After entering the initial parameters we define the scenario of catastrophic events as a unsealing of transmission pipeline. Characterizing transmission pipeline give it a length, which is $50 \mathrm{~m}$ and a diameter equal to $0.2 \mathrm{~m}$. We assume that the inner surface of the tube is smooth. In addition, an estimate of the amount of a chemical that can leave the transmission pipeline must be supported by information on the merger of the pipeline. In this case, we assume that the pipeline is directly connected to a storage tank. Values of pressure and temperature of gas in the pipeline are $4 \mathrm{~atm}$ and $10^{\circ} \mathrm{C}$.

For the calculations of the dangerous substance spread, we had to also define the terrain of the study area. The area we set as a flat and non-urbanized. 
In practice, the use of modelling software catastrophic events leading to obtain qualitative information about the scale of the hazards. In the event of catastrophic events most often seeks to determine the three kinds of information:

- the time at which the chemical is flows out into the environment;

- impact range of the events in the direction taking into account the prevailing meteorological conditions in the area of simulation;

- to estimate the concentration of the chemical as a function of distance and time of the leak.

\subsection{Simulation results}

After entering the required data to ALOHA, adopted as described in section 4.1 of the report and the graphical representation of the results was generated (Fig. 3-5). Were determined area on the levels of 1000,10 and $0.02 \mathrm{ppm}$. The maximum range of the first zone $(1000 \mathrm{ppm})$ is $401 \mathrm{~m}$, tor the second zone $(10 \mathrm{ppm})$ is $4.5 \mathrm{~km}$ and for the third zone $(0.02 \mathrm{ppm})$ is above $10 \mathrm{~km}$.

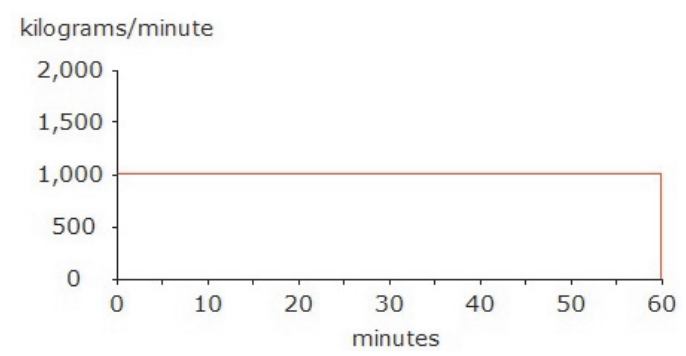

Fig. 3. Amount of chemical substance escapes from the storage tank as a function of time

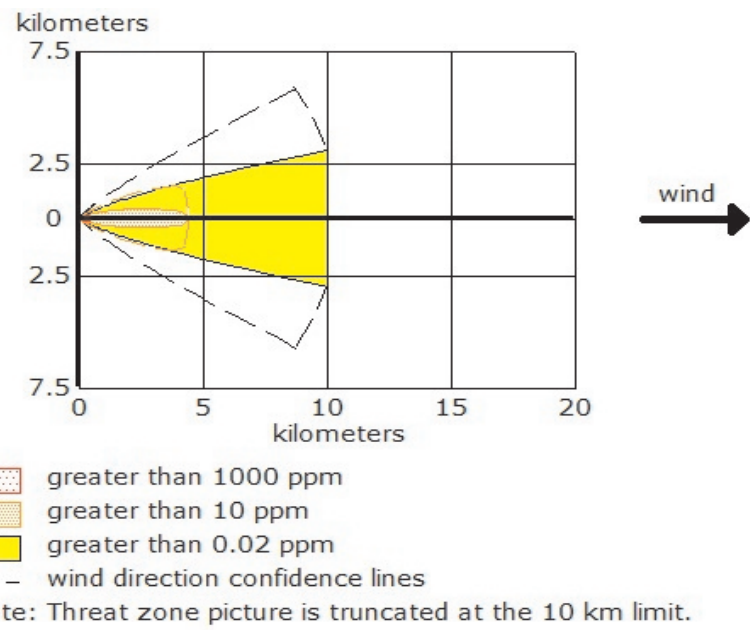

Fig. 4. The impact of the leak of the chemical with marked toxicological thresholds concentration of a hazardous substance 


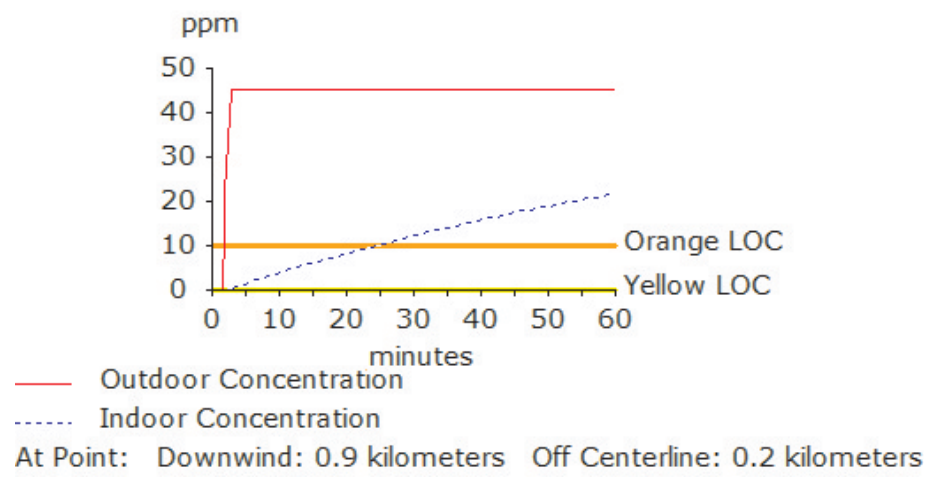

Fig. 5. The values of the concentration of a chemical substance as a function of time in a given geographical location

Presented simulation results allow to estimate the danger zone and support the decision to evacuate. This information are a very important elements for rescuer in charge of the rescue operation. They help not only to determine the danger zone for hazardous substances (Fig. 4), but also helps to estimate the effects of possible explosions. The exact location and size of the designated areas are of great importance when carrying out the evacuation and assessment of the amount of manpower and resources needed to efficiently secure the scene. The rescue action as a result of the spread of hydrogen sulphide is very dangerous, and due to the characteristics of the gas and the complexity of the problem. Correct determination of the hazard zone is therefore a very important element for safety reasons, not only rescuers taking part in the activities, but also bystanders.

\section{CONCLUSIONS}

ALOHA computer program to estimate the range of impact of released into the atmosphere of hazardous chemical pollutant gases allows for an evaluation of the time and scale of the hazard and visualization of simulation results in the form of clear images. One possibility is to present an amount of chemical spills release of / storage tank / pipeline transmission as a function of time, or the term "striking source". Another possibility is a schematic diagram of a generated event be exposed in the direction with marked concentration values and determining the level of exposure of the body in contact with the chemicals. But the most important appears to be possible to determine the estimated concentration of the chemicals as a function of distance and time of the leak taking into account the meteorological conditions in the area of the simulation. The advantage of the model is also that it can freely shape in time and space, such parameters as pollutant emissions, atmospheric conditions or conditions occurring within the area of simulation. In addition, ALOHA is a program shared on the principles of free license which makes 
it accessible to a wider range of customers. Also with low requirement of the system, software can be installed on PCs or laptops, so it can be used in a field improving safety.

\section{REFERENCES}

[1] Atel A.: Symulacja komputerowa jako narzędzie przewidywania skutków katastrof w przemyśle chemicznym. Problemy Ekologii, vol. 11, No. 3, 2007.

[2] Brzozowska L., Dunat R.: Modelowanie propagacji związków niebezpiecznych uwolnionych w wyniku zdarzenia drogowego. Logistyka, No. 4, 2014, pp. 128-136.

[3] Gishkelyuk I.A., Evlanov D.V., Kovalenko V.I.: Computer Modeling of Environmental Problems in the Oil and Gas Industry. Neft. Gaz. Novatsii (The Russian scientific and technical journal, Oil. Gas. Innovations), No. 10, 2013.

[4] Janoszka K., Wziątek A., Gromiec J.P.: Ocena metod monitoring stężeń siarkowodoru w powietrzu. Instytut Medycyny Pracy im. prof. J. Nofera w Łodzi, Medycyna Pracy, 64(3), 2013.

[5] Koutsyn P.V., Gendel G.L.: New Strategy of Controlling Risks in Development of Oil \& Gas Fields with Hydrogen Sulphide. The Fourth International Conference on Health, Safety \& Environment in Oil and Gas Exploration and Production (HSE), 7-10 June, 1998, Caracas, Venezuela.

[6] Majder-Łopatka M., Salamonowicz Z.: Prognozowanie zasięgu strefy zagrożenia toksycznego przy pomocy programu komputerowego ALOHA. Szkoła Główna Służby Pożarniczej, Zakład Ratownictwa Chemicznego, Warszawa 2013.

[7] Michalczyk J.K.: Transport gazowych zanieczyszczeń w powietrzu - symulacje numeryczne w skali lokalnej. Ph.D. thesis. Instytut Inżynierii Ochrony Środowiska, Politechnika Lubelska, Lublin 2003.

[8] Rozporzadzenie Ministra Gospodarki z dnia 28 czerwca 2002 r. w sprawie bezpieczeństwa $i$ higieny pracy, prowadzenia ruchu oraz specjalistycznego zabezpieczenia przeciwpożarowego $w$ zakładach górniczych wydobywajacych kopaliny otworami wiertniczymi. Dz.U. Nr 109, poz. 961, z 2004 r. Nr 24, poz. 213 oraz z 2007 r. Nr 106, poz. 726.

[9] Surygała J., Raczkowski J., Steczko K.: Zagrożenia ekologiczne i ochrona środowiska podczas poszukiwań $i$ wydobycia ropy naftowej. In: Surygała J. (Ed.) Ropa naftowa a środowisko przyrodnicze. Oficyna Wydawnicza Politechniki Wrocławskiej, Wrocław 2001, pp. 47-83.

[10] Uliasz-Misiak B.: Ryzyko środowiskowe związane z eksploatacją złóż węglowodorów zawierajacych siarkowodór. Rocznik Ochrona Środowiska, vol. 17, 2015, pp. 1498-1511.

[11] US Environmental Protection Agency: The CAMEO Software System - ALOHA user's manual. National Oceanic and Atmospheric Administration, 2007.

[12] Wyższy Urząd Górniczy: Ocena stanu bezpieczeństwa pracy, ratownictwa górniczego oraz bezpieczeństwa powszechnego $w$ związu z działalnościa górniczo-geologiczna w 2014 roku. WUG, Katowice 2015. 